\title{
The Influence of Transformational Leadership Style on Innovation Mediated by Organizational Culture
}

\author{
Yasmin Chairunisa Muchtar \\ Faculty of Economics and Business \\ Universitas Sumatera Utara, Medan, Indonesia \\ Inneke Qamariah (Corresponding author) \\ Faculty of Economics and Business \\ Universitas Sumatera Utara, Medan, Indonesia \\ E-mail: inneke.qamariah.feusu@gmail.com
}

Received: May 20, 2014

Accepted: Sep. 27, 2014

Published: October 31, 2014

doi:10.5296/jmr.v6i4.6511

URL: http://dx.doi.org/10.5296/jmr.v6i4.6511

\begin{abstract}
PT. Bakrie Telecom, Tbk is the only private company in the telecommunication industry as the main competitor of PT. Telekomunikasi Indonesia, Tbk which sees innovation as having a vital role to boost performance and competitiveness. Meanwhile, the leadership style is highlighted as one of the most important influences on organizational innovation, as well as organizational culture that is essentially used as a variable in creating and implementing organizational innovation. Therefore, this study aims to analyze the extent to which innovation has been applied to PT. Bakrie Telecom, Tbk and the effect of transformational leadership and the organizational culture to innovation. The data has been collected by using questionnaires with the samples of 83 employees who work in the Marketing Department at PT Bakrie Telecom, Tbk (Northern Region of Sumatera). Then, the data were analyzed using the Path Analysis model, Sobel Test and Bootstrapping. The results show that transformational leadership contributed $43.3 \%$ in explaining the organizational culture, while the transformational leadership insignificantly affected the innovation. Moreover, the transformational leadership had a direct effect to the organizational culture. Finally this study reconfirms that organizational culture mediates the relationship between transformational leadership and innovation.
\end{abstract}

Keywords: Transformational Leadership, Organizational Culture, Innovation in organization 


\section{Introduction}

The cellular phone telecommunications have developed rapidly in Indonesia over the past 15 years as noticed by the increase in the number of subscribers annually (where it reached 10.5 million and grewby $31 \%$ in 2010). Currently, Indonesia is the fourth largest in the number of cellular phone subscribers after South Korea, China and Japan which has 7 operators of cellular phone using the technology of the GSM (Global System for Mobile) and 4 operators with the technology of the CDMA (Code Division Multiple Access). By the end of 2010, the number of cellular subscribers was expected to reach 211 million with GSM operators dominated by $95 \%$, and the CDMA having a 5\% of cellular market shares ${ }^{1}$. Meanwhile, based on a research done by MARS Indonesia in "Indonesian Consumer Profile 2008", the market for the CDMA is dominated by two major telecommunication companies, namely; PT. Telekomunikasi Indonesia, Tbk (Flexi) and PT. Bakrie Telecom, Tbk (Esia). PT. Telekomunikasi Indonesia, Tbk is owned by the Indonesian government and PT. Bakrie Telecom, Tbk is the only private company in this industry which stands as the main competitor of PT. Telekomunikasi Indonesia, Tbk

Under these conditions, the innovation plays an important role for any organizations. The previous researches have recommended that an organizational innovation affects performance and competitiveness (Baker \& Sinkula, 2002). The concept of innovation isused as a competitive mechanism of the firms' performance towards success that crucially needs to be adapted in facing the changes in the business environment by obtaining the competitive advantage and facilitating all related activities (Perry-Smith, 2006). Thus, an organization must enhance the organizational innovativeness to be competitive (Lengnick-Hall, 1992; Roberts, 1998).

Leadership style has been highlighted as one of the most important influences on organizational innovation both in private and public sectors. This leadership style which supports the organizational innovationis known as transformational leadership style that functions to motivate the employees and help to introduce an organizational culture which promotes creativity and risk taking (Scott \& Bruce, 1994). The organizational culture is one of the essential variables used to create and implement innovation in organization that shapes the values and beliefs (Denison, 1990). These values and beliefs are suggested to be shared among all members of an organization.

Based on the arguments above, this study aims to analyze the extent to which innovation has been applied by PT. Bakrie Telecom, Tbk and the effect of transformational leadership, organizational culture to innovation. It is important for PT Bakrie telecom, Tbk to maintain the performance and gain the opportunity in seizing a larger market for the CDMA market due to the significant increment in the number of subscribers each year. The limited studies on telecommunication companies in Indonesia would be another justification that makesthis study salient. Thus, the objective of this research is to investigate the influence of the leadership style on innovation in telecommunication companies which is mediated by the factor of organizational culture.

${ }^{1}$ http://www.datacon.co.id/Telecommunications-2011Profile.html, retreived on August 28th 2014. 


\section{Literature Review}

\subsection{Transformational Leadership on Innovation}

Leadership is the ability to inspire confidence and support among the people in achieving organization goals, while a leader has a relatively consistent pattern of behavior (Dubrin, 2001). Due to the prominent position within organizations, the top leaders are uniquely capable of recognizing environmental trends and changes in initiating an innovative measure to achieve organizational effectiveness (Elenkov et al., 2005).Moreover, leaders of today face an extremely dynamic environment that has tremendous change. Thus, to effectively deal with those changes, the leaders must share their vision while the workers in organizations should be willing to commit themselves to accomplishing the leader's direction (Baum \& Locke, 2004; Northouse, 2007).

In general, it is suggested that a leader is an important factor that has a powerful source of influencing employees in the dynamic nature of competitive environments (Elkins \& Keller, 2003; Yukl, 2002). Meanwhile, the transformational leaders are able to provide vision, motivate employees, and help to instill an organizational culture which encourages creativity, risk taking, and nurtures the innovation (Scott \& Bruce, 1994). Moreover, the role of top management becomes even more crucial in cultivating a strong organizational culture which encourages innovation. Previous studies have shown that transformational leadership can be instrumental in shaping an innovation by encouraging the adoption of culture (Scott \& Bruce, 1994).

\section{H1: Transformational Leadership has direct effect to Innovation}

\subsection{Transformational Leadership on Organizational Culture}

Karami et al. (2010) conclude that there is a direct relationship between transformational leadership style and organizational culture. In the organizational perspective, an organizational culture is used as a strong chain by which an organization becomes stable (Bidokhti, 2000, p.7) andit is made of values on which the intra- organizational behaviors are shaped, hence, the organization's members intervene in such values.

H2: Transformational Leadership has direct effect to the Organizational Culture.

\subsection{Organizational Culture on Innovation}

In the innovation-relatedliterature, it is mentioned that organizational culture plays an important role in influencing organizational innovations (Yang, 2007; Martins \& Terblanche, 2003). Generally, the innovation process is segregated into two main phases: initiation and implementation (Zaltman et al., 1973), while Rickards (1985) defines innovation as the generation of a new idea and its implementation into a new product, process, or service. Other researchershave defined it as an adoption of new idea or behavior pertaining to a device, system, process, policy, program, product or service of the organization (Daft, 1982; Zaltman et al., 1973), andthat it indicates successful implementation of creative ideas within an organization (Amabile et al., 1996). Innovation is a complex process which requires the use of knowledge increating and applying an idea that is new to the market. Rickards (1985) 
considers innovation as a processwhere new ideas are put into practice. Meanwhile, organizational innovation is referred as the creation of valuable and useful new products and services within an organizational context (Woodman et al., 1993).

For many decades, the researchers have determined that an organization's culture could be the genesis of a significant competitive advantage in the business environment. The organization's culture consists of assumptions, values and beliefs that are shared or re-produced with the permission of the copyright owner. It forms a construct reflecting the values and beliefs that lie at the core of the organizations and is able to reinforce the organization's management practices and employees' behavior (Denison, 1990). In addition, Forehand and von Gilmer (1964) suggest that organizational culture is aset of characteristics that describe an organization and distinguish it from others. With this explanation, the culture becomes one of the most powerful and stable forces operatingin organizations (Schein, 1996), therefore, organizations should increase their organizational innovativeness through cultures to remain competitive (Lengnick-Hall, 1992; Roberts, 1998).

H3: Organizational culture mediates the relationship between transformational leadership and innovation.

\section{Research Methodology}

\subsection{Population and Sample}

This research was conducted in Medan City with the sampleof employees who are working at PT. Bakrie Telecom, Tbk (Northern Region of Sumatera) in the Marketing Department. Samples were gathered by using purposive sampling. The data were collected through self-administered questionnaires that were delivered via emails. A total of 83 questionnaires were distributed to the respondents, and all of them were returned. The instruments used to measure the variables werein a semantic differential scale from 1 (strongly disagree) to 5 (strongly agree).

\subsection{Hypothesis testing}

The hypothesis testing on the level of acceptance or rejection is at $p=.05$ in the equation and beta coefficient value produced by a multiple linear regression analysis (Ghozali, 2011). The regression analysis assumes that the data are linear, normal, and free from homoscedasticity and multicollinearity problems. This research uses SPSS software version 20.

\subsubsection{Path Analysis}

Path analysis is an extension of the multiple regression analysis that is used to estimate the causal relationship between variables predetermined by the theory. The influence of the mediating variables can be detected directly by viewing the model as follows:

$$
\begin{gathered}
Y=a 1+c X \\
Y=a 2+a X \\
Y=a 3+c^{\prime} X+b M
\end{gathered}
$$




\subsubsection{Sobel and Bootstrapping Tests}

The mediation hypothesis testing can be done with a procedure developed by Sobel (1982) known as the Sobel test. This test requires the assumption of large sample size and the mediation coefficient of normal distribution. Bootstrapping is a non-parametric approach that does not assume the shape of the distribution of variables and can be applied witha small sample size.

\section{Data Analysis and Findings}

\subsection{Path Analysis}

The First Equation

Organizational Culture $=\alpha+\mathrm{p} 2$ Transformational Leadership $+\mathrm{e} 1$.

Table 1. Model Summary

\begin{tabular}{|l|l|l|l|l|}
\hline Model & $\mathrm{R}$ & $\begin{array}{l}\mathrm{R} \\
\text { Square }\end{array}$ & Adjusted R Square & Std. Error of the Estimate \\
\hline 1 & $.658^{\mathrm{a}}$ & .433 & .426 & 7.668 \\
\hline
\end{tabular}

a. Predictors: (Constant), TL

As shown in Table 1, the R-Square of the Model is 0.433 , implying that the transformational leadership contributed to $43.3 \%$ in explaining the organizational culture, while the rest of $56.7 \%$ were explained by other variables which are not discussed in this study.

Table 2. Coefficients

\begin{tabular}{|l|l|l|l|l|l|}
\hline \multirow{2}{*}{ Model } & \multicolumn{2}{|l|}{$\begin{array}{l}\text { Unstandardized } \\
\text { Coefficients }\end{array}$} & $\begin{array}{l}\text { Standardized } \\
\text { Coefficients }\end{array}$ & t & \multirow{2}{*}{ Sig. } \\
\cline { 2 - 6 } & $\mathrm{B}$ & Std. Error & Beta & 4.212 & .000 \\
\hline (Constant) & 20.529 & 4.874 & & 7.871 & .000 \\
\hline TL & .778 & .099 & .658 & & \\
\hline
\end{tabular}

a. Dependent Variable: OC

The Table 2 shows that the significant value of transformational leadership was 0.000 . It means that the transformational leadership significantly affects the organizational cultures.

The Second Equation:

$$
\mathrm{I}=\alpha+\mathrm{p} 1 \mathrm{TL}+\mathrm{p} 3 \mathrm{OC}+\mathrm{e} 2
$$


Table 3. Model Summary

\begin{tabular}{|l|l|l|l|l|}
\hline Model & $\mathrm{R}$ & $\begin{array}{l}\mathrm{R} \\
\text { Square }\end{array}$ & Adjusted R Square & Std. Error of the Estimate \\
\hline 1 & $.750^{\mathrm{a}}$ & .563 & .552 & 6.787 \\
\hline
\end{tabular}

a. Predictors: (Constant), OC, TL

As shown in Table 3, the R-Square of the Model was 0.563, meaning that the transformational leadership and organizational culture variables contributed to $56.3 \%$ in explaining the organizational innovation, while the rest of $43.7 \%$ were explained by other variables which are not discussed in this study.

Table 4. Coefficients

\begin{tabular}{|l|l|l|l|l|l|}
\hline \multirow{2}{*}{ Model } & \multicolumn{2}{|l|}{$\begin{array}{l}\text { Unstandardized } \\
\text { Coefficients }\end{array}$} & $\begin{array}{l}\text { Standardized } \\
\text { Coefficients }\end{array}$ & $\mathrm{t}$ & Sig. \\
\cline { 2 - 6 } & $\mathrm{B}$ & Std. Error & Beta & \\
\hline (Constant) & -1.337 & 4.763 & & -.281 & .780 \\
\hline TL & .006 & .116 & .005 & .050 & .961 \\
\hline OC & .748 & .098 & .747 & 7.603 & .000 \\
\hline
\end{tabular}

a. Dependent Variable: I

In Table 4, it shows that the significant value of transformational leadership was 0.961 , and this means that the transformational leadership insignificantly affects the innovation. It also shows that the significant value of organizational cultures was 0.000 , meaning that the organizational cultures significantly affect innovation.

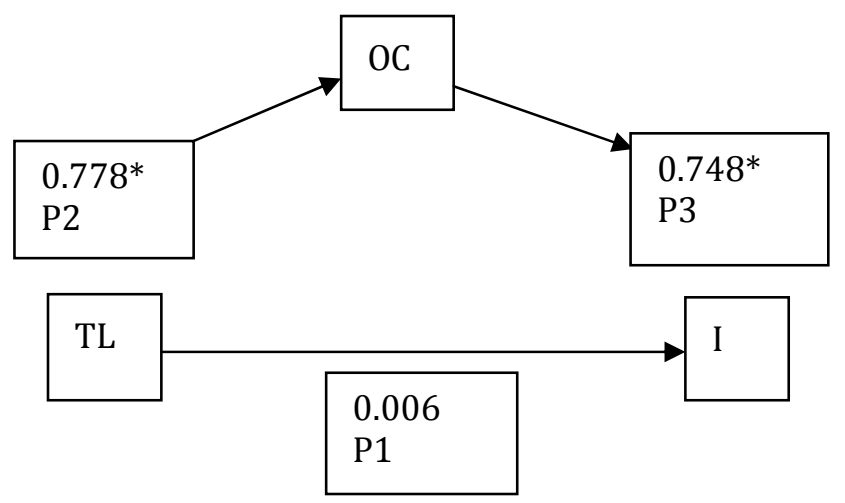

Figure 2. Path Analysis 
Table 5. Total Effect of Transformational Leadership to Innovation

\begin{tabular}{|lll|l|}
\hline $\begin{array}{l}\text { Direct Effect of Transformational Leadership to } \\
\text { Innovation }\end{array}$ & $=0.006$ \\
\hline $\begin{array}{l}\text { Indirect Effect of Transformational Leadership to } \\
\text { Organizational Cultures to Innovation }\end{array}$ & $=(0.778 \times 0.748)$ \\
\hline $\begin{array}{l}\text { Total Effect of Transformational Leadership to } \\
\text { Innovation }\end{array}$ & $=0.588$ \\
\hline
\end{tabular}

Table 5. illustrates that the direct effect of transformational leadership to innovation was 0.006 and the indirect effect of transformational leadership to organizational cultures to innovation was 0.582 . Consequently, the total effect of transformational leadership to innovation was 0.588 .

\subsection{Sobel Test}

Mediation Effect of Organizational Cultures between Transformational Leadership and Innovation.

$$
\begin{aligned}
& \mathrm{Sp} 2 \mathrm{p} 3=\sqrt{\mathrm{p}} 3^{2} \mathrm{Sp} 2^{2}+\mathrm{p} 2^{2} \mathrm{Sp} 2^{2} \mathrm{Sp} 3^{2} \\
& =\sqrt{ }(0.748)^{2}(0,099)^{2}+(0,778)^{2}(0,098)^{2}+(0,099)^{2}(0,098)^{2} \\
& =\sqrt{ }(0,559)(0,0098)+(0,6)(0,0096)+(0,0098)(0,0096) \\
& =\sqrt{ } 0,0055+0,0057+0,00009 \\
& =\sqrt{ } 0,0113 \\
& =0,106 \\
& \mathrm{t}=\underline{\mathrm{p} 2 \mathrm{p} 3}=\underline{0,778(0,748)}=\underline{0,607}=8,2 \\
& \text { Sp2p3 } \quad(0,099)(0,748) \quad 0,074
\end{aligned}
$$

According to the calculation above, the $\mathrm{t}$ value is $8.2>\mathrm{t}_{\text {table }}(1.96)$, and it demonstrates that there is a mediation effect. It shows that, organizational culture mediates the relationship between transformational leadership to organizational innovation.

\subsection{Bootstrapping.}


Table 6. Result of Bootsrapping

\begin{tabular}{|l|ll|l|}
\hline $\mathrm{b}(\mathrm{YX})$ & 0,5875 significant 0,000 & $\begin{array}{l}\text { Total effect of transformational leadership to } \\
\text { innovation }\end{array}$ \\
\hline $\mathrm{b}(\mathrm{MX})$ & $\begin{array}{l}0,778 \text { significant value is } \\
0,000\end{array}$ & $\begin{array}{l}\text { The effect of transformational leadership to } \\
\text { organizational culture. }\end{array}$ \\
\hline $\begin{array}{l}\text { b } \\
(\text { YM.X) }\end{array}$ & $\begin{array}{l}0,7477 \text { significant value is } \\
0,000\end{array}$ & $\begin{array}{l}\text { The effect of mediated variable (organizational } \\
\text { culture) to organization innovation by } \\
\text { controlling the transformational leadership. }\end{array}$ \\
\hline $\begin{array}{l}\text { b } \\
(Y X . M)\end{array}$ & $\begin{array}{l}0,0058 \text { significant value is } \\
0,9606\end{array}$ & $\begin{array}{l}\text { Direct effect of transformational leadership to } \\
\text { organization innovation by controlling } \\
\text { organizational culture }\end{array}$ \\
\hline
\end{tabular}

The indirect effect of transformational leadership to organizational innovation through organizational culture is 0.5817 with the significant value 0.000 . The value of the standard error of bootstrapping with normal distribution assumption is 0.0977 . Therefore the $t$ value of the indirect effect by using bootstrapping is:

$$
\mathrm{t}=\underline{0.5817}=5.95
$$

It shows that $t$-value $(5.95)>t_{\text {table }}(1.96)$, so that it supports the previous result of the Sobel Test where organizational culture mediates the relationship between transformational leadership to organizational innovation.

\section{Discussion and Conclusion}

The results of this study establishthat transformational leadership significantly affects the organizational culture. Referring to Karami et al. (2010), there is a relationship between transformational leadership style and organizational culture. The organizational culture which carries values and beliefs that have been applied by all organization members are useful and crucial in facing an extremely dynamic environment. Hence, the transformational leader needs to disseminate the culture effectively to achieve organizational success.

Meanwhile, it is found that transformational leadership insignificantly affects the innovation. It is not in line with the theory posited by Scott \& Bruce (1994), who explain that the transformational leadership style is able to encourage creativity and nurture the organizational innovation. This means that the leaders adopting transformational leadership style cannot create and implement the innovation in their organizations without having to consider the adoption of the organizational culture which brings values and beliefs. Nevertheless, the 
leadership remains as an important factor that affects organizational innovation through the full support of the organizations' system, rules, policy, values and belief, where this condition is applied in PT. Bakrie Telecom, Tbk. Moreover, it is found that organizational culture significantly affects the innovation. This has been agreed by Carmeli (2005) that the organizational culture is one of the variables which are considered to have an important impact on innovation. Consequently, all the members in the organization must accept an innovation as a basic value, which will be shared and implemented by them (Hartman, 2006). In PT. Bakrie Telecom, Tbk, such practice of infusing culture with innovation hasbeen adopted by all members of the organization. It is also assumed that PT Bakrie Telecom, Tbk has successfully implemented creative ideas within an organization.

Theresults of this study reconfirm that the organizational culture mediates the relationship between transformational leadership and innovation, and this is supported by Scott \& Bruce (1994). They have posited that the role of top management becomes even more important in establishing a strong organizational culture that supports the innovation. As a matter of fact, implementing innovation in an organization is not a simple task. It is indeed a complex process requiring the knowledge to create and execute something new to the market. According to Woodman et al. (1993), the organizational innovation is the design of useful new products and services in organizational context, therefore innovation would be successfully implemented by the transformational leaders in an organization that has a strong organizational culture.

\section{References}

Amabile, T., Conti, R., Coon, H., Lazenby, J., \& Herron, M. (1996). Assessing the work environment for creativity. Academy of Management Journal, 39(5). 1154-84. http://dx.doi.org/10.2307/256995

Baker, W.E., \& Sinkula, J.M. (2007). Does market orientation facilitate balanced innovation programs? An organizational learning perspective. Journal of product innovation management, 24, 316-34. http://dx.doi.org/10.1111/j.1540-5885.2007.00254.x

Baum, J., \& Locke, E. (2004). The relationship of entrepreneurial traits, skill, and motivation to subsequent venture growth. Journal of Applied Psychology, 89(4), 587-98. http://dx.doi.org/10.1037/0021-9010.89.4.587

Bidokhti, H. (2000). Organizational culture, areas of origin and be the Year IX, 58, 6-13.

Carmeli, A. (2005). The relationship between Organizational culture and withdrawal intentions and behavior. International Journal of Man power, 26(2), 177-95. http://dx.doi.org/10.1108/00251741111094437

Daft, R. (1982). Bureaucratic versus non-bureaucratic structure and the process of innovation and change in Bacharach, S.B. (Ed.), Research in the Sociology of Organizations. Greenwich, CT: JAI Press.

Denison, D. (1990). Corporate Culture and Organizational Effectiveness. New York: Wiley. 


\section{Macrothink}

Journal of Management Research ISSN 1941-899X 2014, Vol. 6, No. 4

Dubrin, A.J. (2001). Leadership-Research finding, practices, and skills. 3rd eds. Boston: Houghton Mifflin.

Elenkov, D., Judge, W., \& Wright, P. (2005). Strategic leadership and executive innovation influence: an international multi-cluster comparative study. Strategic Management Journal, 26, 665-82. http://dx.doi.org/10.1002/smj.469

Elkins, T., \& Keller, R. (2003). Leadership in research and development organizations: a literature review and conceptual framework. Leadership Quarterly, 14, 587-606. http://dx.doi.org/10.1016/S1048-9843(03)00053-5

Forehand, G.A., \& von Gilmer, B. (1964). Environmental variations in studies of organizational behavior. Psychological Bulletin, 62, 361-382. http://dx.doi.org/10.1037/h0045960

Ghozali (2011). Analysis Multivariate with Program IBM SPSS 20. Diponegoro University Press. Semarang.

Hartmann, A. (2006). The role of organizational culture in motivating innovative behaviour in construction firms. Construction Innovation, 6(3), 159-72. http://dx.doi.org/10.1108/14714170610710712

Karami, N. R., Salimi, H., \& Amini, A. (2009). Relationship between leadership style and organizational commitment in military culture. Journal of Military Medicine, 12(2), 65-70.

Lengnick-Hall, C. (1992). Innovation and competitive advantage: what we know and what $\begin{array}{llll}\text { weneed to learn. Journal of } & \text { 39anagement, } 42 .\end{array}$ http://dx.doi.org/10.1177/014920639201800209

Martins, E.C., \& Treblanche, F. (2003). Building Organizational Culture that stimulate creativity and innovation. European Journal of Innovation Management, 6(1), 64-74. http://dx.doi.org/10.1108/14601060310456337

Northouse, P. (2007). Leadership: Theory and Practice, 4th ed. CA: Sage, Thousand Oaks.

Perry-Smith, J. E. (2006). Social yet creative: The role of social relationship in facilitating individual creativity. Academy of Management Journal, 49(1), 85-101. http://dx.doi.org/10.5465/AMJ.2006.20785503

Rickards, T. (1985). Stimulating Innovation - A Systems Approach. British Library Cataloguing in Publication Data, London.

Roberts, R. (1998). Managing innovation: the pursuit of competitive advantage and the design of innovation intense environments. Research Policy, 27(2), 159-75. http://dx.doi.org/10.1016/S0048-7333(98)00034-1

Schein, E.H. (1985). Organizational culture and leadership. San Francisco, CA: Jossey-Bass. 


\section{Macrothink}

Journal of Management Research

ISSN 1941-899X 2014, Vol. 6, No. 4

Scott, S.G., \& Bruce, R.A. (1994). Determinants of innovative behavior: A path model of individual innovation in the workplace. Academy of Management Journal, 37(3), 580-607. http://dx.doi.org/10.2307/256701

Sobel, M.E. (1986). Some New Results on Indirect Effects and their Standard Error in Covariance Structure Models. In N Tuma (Ed), Sociological Methodology. 159-186. Washington DC: American Sociological Association.

Woodman, R., Sawyer, J., \& Griffin, R. (1993). Toward a theory of organizational creativity. Academy of Management Review, 18(2), 293-321.

Yang, J.T. (2007). Knowledge Sharing: Investigating appropriate leadership roles and collaborative culture. Tourism Management, 28(2), 530-43. http://dx.doi.org/10.1016/j.tourman.2006.08.006

Yukul, G. (2002). Leadership in Organizations. 5th ed., Prentice-Hall, Englewood Cliffs, NJ

Zaltman, G., Duncan, R., \& Holbeck, J. (1973). Innovations and Organizations. New York: Wiley. 